\title{
Enhancing the livelihood of Himalayan communities through action research and transforming wild produce into high-value products
}

\author{
Meenakshi Garg*, Mahendra Singh Kunwar and Hema Kashyap \\ Himalayan Action Research Centre, Dehradun 248 006, India
}

Deterioration in traditional mountain food systems with a decline in agro-biodiversity has made the Himalayan communities more sensitive to environmental degradation. Wild edible varieties from marginal land have shown great characteristics and resistance to the adverse climate changes. This study was conducted to promote and transform the lesser known wild edible produces of Uttarakhand, India into marketable highvalue products through scientific technologies. On the basis of their availability and ethno-botanical properties, eight wild produces were selected. Demographically, 4097 households belonging to 36 villages of two selected districts of Uttarakhand were targeted as major beneficiaries. The complete scope study was carried out in four blocks of Chamoli and one block of Rudraprayag district of Uttarakhand. Thereafter, the procurement of wild produces was carried out with complete involvement of stakeholders from 54 villages. The entire research and development was carried out in an Women's Cooperative Centre equipped with modern machinery. Linkage with several research institutions related to product design, processing and preservation was also done to improvize the quality and presentation of the high-value products. Under this intervention, 19 high-value products were successfully developed and launched by the Himalayan Action Research Centre, Alaknanda Women's Cooperative. Thus, local relationship and linkage among the stakeholders were strengthened for sustainable development and intervention of a replicable model in the Himalayan region of Uttarakhand.

Keywords: Action research, high-value products, livelihood enhancement, mountain food systems, wild produce.

\section{Introduction}

THE Himalaya may be rugged and majestic, but also has fragile environmental conditions that are extremely vulnerable to climate change. Presently, sustainable live-

\footnotetext{
*For correspondence. (e-mail: meegarg14@gmail.com)
}

lihood is the biggest challenge for Himalayan communities. While the agriculture of Uttarakhand is struggling to cope with climatic change, wild edibles have emerged as sustainable options that can provide communities a leeway to sustain their livelihoods. Wild edible plants are an important source of supplement/substitute food in times of scarcity for the native communities. Being wild, these edibles from marginal land have shown great resistance to adverse climate changes. Wild fruits grown in forest areas without much care are important for the poor communities, rural populations and women, particularly during critical food shortage and other extreme situations like natural calamities, thereby offering an alternative for achieving food security. These non-conventional wild food plants are accredited as a rich source of nutrients than conventional food crops and have therapeutic properties as well.

According to a study ${ }^{1}$, wild fruits have much more nutritional value than cultivated ones as well as have more resistance towards climate change. Therefore, converting underutilized, surplus wild varieties of Uttarakhand into high-value products will strengthen the Himalayan communities to cope with the effects of socioeconomic and environmental changes by providing nutritional security, high-value products, innovative livelihood options and rural income generation strategies through forests. This study was conducted to promote wild edibles as a link among communities, science and culture. The concept can be strengthened to maintain not only the biodiversity of the region, but also sustain livelihood of the communities of the region. Major objectives of the study were:

- To undertake action research based intervention and convert low-value wild produce into high-value products.

- To use traditional knowledge and promote high-value products, thereby benefitting rural communities, especially women and consumers.

- To establish a successful community model that is replicable and to promote sustainable use of natural and wild products of the Himalayan region. 


\section{Review of the literature}

Wild fruiting plants are found in abundance in places that are not affected by human interaction due to their difficult geographic and climatic conditions which are not suitable for human survival. In 2010, Tiwari et al. ${ }^{1}$, surveyed the ethno-botanical exploration, identification, concerns and future potentialities of the wild edible plants of Srinagar and Alaknanda valley of Garhwal Himalaya and recorded total 55 plant species belonging to 35 families. Uttarakhand is among those places which are suitable for wild edible fruiting plants because of its difficult geography and climatic conditions, and good taste of fruits which attracts the local people as a rich source of nutrition ${ }^{2}$.

The unique diversity of such important plants in the region is manifested by the presence of numerous native (31\%), endemic (13.5\%) and threatened (14\%) species mentioned in red data book of Indian Himalayan region ${ }^{3}$. According to Uniyal and Shiva ${ }^{4}$, women of the Himalayan region have an intimate and long association with the surrounding forests for fulfilling their daily needs of fuel, fodder and forest produce. The Himalayan communities can use small and medium enterprises to generate employment in extractive operations, but only about a third of the workers in these enterprises are women ${ }^{5}$.

The use of plant species of the Himalaya as food and medicine has been known for a long time, and about 1748 economically important plants have been reported from the Indian Himalaya ${ }^{6}$. Wild edible plants are important for the well-being of rural populations in the region, not only as a source of supplemental food, nutritionally balanced diet, medicine, fodder and fuel, but also for their income-generating potential ${ }^{6}$. Sustainability of watersheds, livelihood of the villagers, and the status of native flora and fauna depend on the structure, composition and productivity of these forests. On this basis, documentation of knowledge, frequency of use and availability status of wild edible plants and their market potential should be thoroughly studied ${ }^{7}$.

The traditional method of oil extraction has been reported by Sharma et al. ${ }^{8}$, to be unhygienic and result in low oil yield with poor quality. They developed an improved mechanical method of oil extraction to produce good quality oil ${ }^{9}$. Researchers have reported that vitamin C content of sea-buckthorn fruits is 3-4 times higher than that of 'aonla' fruit, and 6-16 times higher than that of kiwi fruit. Vitamin $\mathrm{E}$ and $\beta$-carotene contents of sea buckthorn oil are much higher than those of other nutrient oils. Thus, this wild berry has high potential in today's world $^{10-12}$.

According to a study conducted by an NGO valueaddition is the development of secondary industries to support the Himalayan communities, which in turn generate additional employment ${ }^{13}$. Along with that there should be considerable emphasis on technology infusion and associated skill-building, as well as on entrepreneurship development and infusion of basic management skills.

\section{Materials and methodology}

This study was conducted with the concept of 'food from forest', with a focus on the health and future of Himalayan forests utilizing wild produce for high-value products, which will provide sustainable livelihood and ensure a better future for the Himalayan communities.

\section{Scope study}

Under this study, ten surveys ( 9 baseline surveys and 1 ethno-botanical survey) were conducted in 54 villages of four blocks of Chamoli district (Joshimath, Karanprayag, Pokhri and Ghat block) and one block (Ukhimath) of Rudraprayag district, Uttarakhand, to determine surplus production and traditional knowledge of selected wild produce (Figures 1 and 2). On the basis of availability of raw produce, 36 villages were selected as targeted beneficiaries. Taxonomic identification of eight selected wild produce was also done to identify the surplus species in the targeted area (Table 1).

\section{Research and development}

Selection and procurement: Out of numerous wild edible species, on the basis of their availability and ethnobotanical properties, eight wild produce were procured after conducting harvesting training with key stakeholders of targeted villages and then transported. Standard operating procedures (SOPs) for procurement and storage of wild produce were designed on the basis of action research and gaps. Only $40 \%$ of the produce was harvested in order to restore and maintain biodiversity.

Phytochemical analysis: Phytochemical analysis of the eight selected wild produce was done as shown in Table 2 in order to determine their dietary importance; this was carried out by using standard methods ${ }^{14-16}$. The minor

Table 1. Taxonomic identification of selected wild produce

\begin{tabular}{ll}
\hline Wild produces & \multicolumn{1}{c}{ Scientific name } \\
\hline Wild peach (aadu) & Prunus persica \\
Wild plum (plum) & Prunus domestica \\
Sea buckthorn (chuk/ames) & Hippophae salicifolia \\
Wild walnut (akhrot) & Juglans regia \\
Wild aonla (amla) & Phyllanthus emblica \\
Wild apricot (chullu/khurmani) & Prunus armeniaca \\
Kaphal & Myrica esculenta \\
Mehal & Pyrus pashia \\
\hline
\end{tabular}

Source: The Botanical Survey of India, Dehradun. 


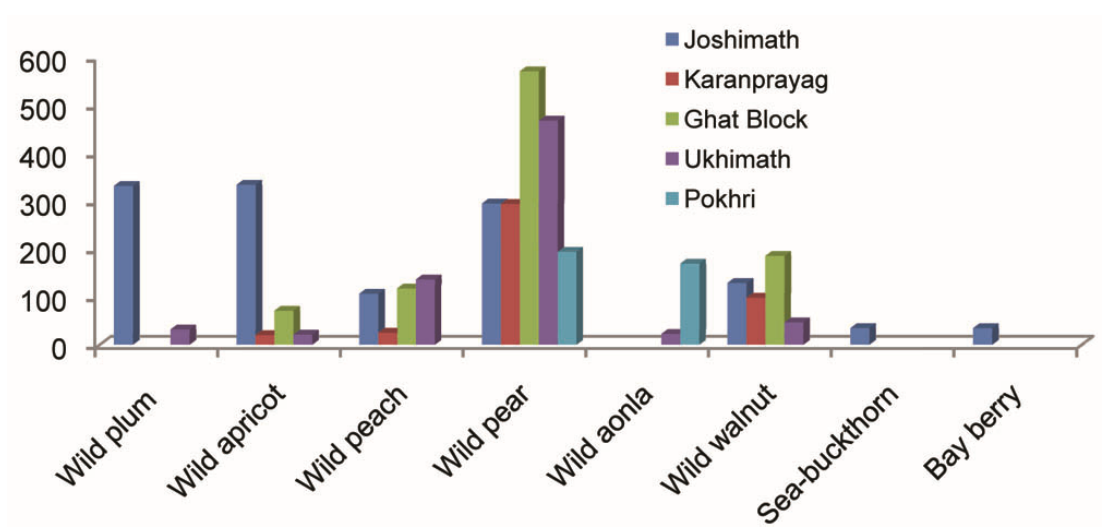

Figure 1. Production assessment (quintals) of five blocks in the project area, Uttarakhand, India. Source: Baseline survey in 2016.

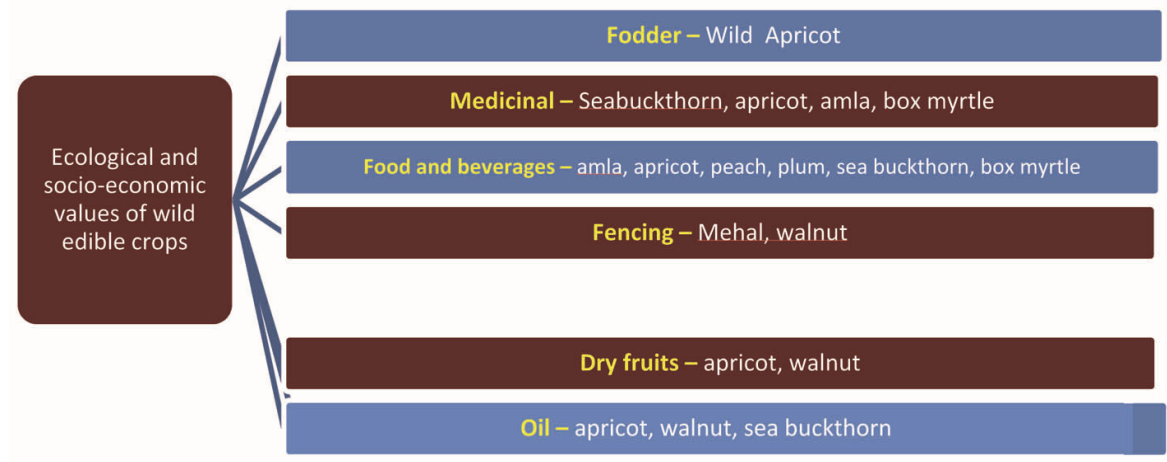

Figure 2. Results of ethno-botanical and ecological survey conducted in the project area in June 2017.

Table 2. Phytochemical analysis of eight selected wild crops

\begin{tabular}{|c|c|c|c|c|c|c|c|c|c|c|}
\hline \multirow[b]{2}{*}{ Components } & \multirow[b]{2}{*}{$\begin{array}{l}\text { Wild } \\
\text { walnut }\end{array}$} & \multicolumn{3}{|c|}{ Wild apricot } & \multirow[b]{2}{*}{ Amla } & \multirow[b]{2}{*}{$\begin{array}{c}\text { Sea } \\
\text { buckthorn }\end{array}$} & \multirow[b]{2}{*}{ Mehal } & \multirow[b]{2}{*}{ Kaphal } & \multirow[b]{2}{*}{$\begin{array}{l}\text { Wild } \\
\text { plum }\end{array}$} & \multirow[b]{2}{*}{$\begin{array}{l}\text { Wild } \\
\text { peach }\end{array}$} \\
\hline & & Fruit & $\begin{array}{l}\text { Sweet } \\
\text { kernel }\end{array}$ & $\begin{array}{l}\text { Bitter } \\
\text { kernel }\end{array}$ & & & & & & \\
\hline Moisture (\%) & 8 & 77.38 & 16 & 16 & 80.2 & 86 & 56 & 72.06 & 82.46 & 63 \\
\hline $\mathrm{pH}$ & - & 3.6 & - & - & 3.8 & 2.8 & 3.4 & 4.3 & 3.2 & 3.8 \\
\hline $\operatorname{TSS}\left({ }^{\circ} \mathrm{B}\right)$ & - & 12.9 & - & - & 11.02 & 10.1 & 9.8 & 19.2 & 9.1 & 6.9 \\
\hline Reducing sugars (\%) & - & 8.82 & - & - & 6.73 & 0.004 & 0.0083 & 15.11 & 6.18 & 4.79 \\
\hline Total sugars (\%) & - & 12.41 & - & - & 7.88 & 0.0134 & 0.028 & 17.11 & 7.54 & 6.43 \\
\hline Titratable acidity (\%) & - & 0.41 & - & - & 3.01 & 23.18 & 2.41 & 2.81 & 3.98 & 0.28 \\
\hline Crude fibre (\%) & & 6.34 & & & 3.4 & 1.09 & 2.96 & 1.02 & 4.08 & 3.2 \\
\hline Total ash & 2.4 & 0.91 & 1.8 & 1.7 & 1.88 & 2.3 & 2 & 1.03 & 0.4 & 0.98 \\
\hline Ascorbic acid (mg/100 g) & - & 4.93 & - & - & 598 & 600 & 1.13 & 4.2 & 9.11 & 6.2 \\
\hline Antioxidant activity (\%) & 27.11 & 20.22 & 58.82 & - & 33.46 & 14.66 & 22.42 & 38.21 & 16.26 & 19.2 \\
\hline Carotene $(\mu \mathrm{g} / 100 \mathrm{~g})$ & - & 2280 & - & - & 6.77 & 240 & 380 & 48 & 2835 & 586 \\
\hline Fat $(g / 100 g)$ & 26.94 & - & 48.26 & - & 0.15 & - & - & - & - & - \\
\hline Phenol (mg/kg) & 1.176 & 0.036 & 10.76 & - & 0.006 & 0.044 & 0.0084 & $\begin{array}{c}1.37 \mathrm{mg} / \\
100 \mathrm{ml}\end{array}$ & 0.05 & 0.04 \\
\hline Oil (g/100 g) & 5.13 & - & 42.28 & - & 0.14 & 6.018 & & - & - & - \\
\hline Oleic acid (g/100 g) & - & - & - & 35.78 & - & - & & - & - & - \\
\hline Amygdalin & & & & 0.89 & & & & & & \\
\hline
\end{tabular}

*Source: In-house and external laboratory (Anacon Laboratory, Nagpur).

analysis of different samples of selected produce (moisture, sugar, ascorbic acid, titratable acidity, crude fibre, ash and TSS) was done in an internal analytical laboratory established at the Common Facility Centre (CFC), where minor analytical instruments and chemicals are available in order to conduct immediate analysis, required after transportation of raw produce, whereas other properties like carotene, phenols, oil, fatty acid, antioxidant activity 


\section{Box 1. Phytochemical parameters}

(1) Moisture: The method involves loss of water through evaporation and drying of sample in hot-air oven $\left(110^{\circ} \mathrm{C}\right)$ for $1 \mathrm{~h}$ or under vacuum $\left(60-70^{\circ} \mathrm{C}\right)$ till it reaches apparent dryness.

(2) Sugar: The sugar of the sample was estimated by determining the volume of unknown sugar solution required to reduce the specific volume of Fehling's solution completely.

(3) Ash: It is estimated by ashing the sample by placing it in a muffle furnace overnight.

(4) Titratable acidity: Determined by titrating the sample with $0.1 \mathrm{~N} \mathrm{NaOH}$ solution and using phenolphthalein as the indicator.

(5) Crude fibre: Organic residue which remains after the sample has been boiled with dilute sodium hydroxide solution.

(6) Ascorbic acid: Vitamin $C$ in the sample is determined by redox titration method (iodine titration).

(7) Total soluble solids: Determined using analytical instrument refractometer.

Table 3. Major equipment installed in CFC Unit under the study

\begin{tabular}{lc}
\hline Equipment & Description \\
\hline Dehydrator & $\begin{array}{c}\text { Dehydrator containing } 40 \text { trays for quality and standardized drying of fruits and vegetables }\left(60^{\circ} \pm 5^{\circ} \mathrm{C}\right) . \\
\text { This is a cost-effective machine that can be separated into two halves according to the requirement. } \\
\text { Highly equipped with transonic radiations and ozone gas for quality, bacteria-free washing of perishable } \\
\text { and highly perishable fruits and berries. }\end{array}$ \\
$\begin{array}{l}\text { Wut and walnut decorticator } \\
\text { Bar-cutting and packaging machine } \\
\text { Cold storage }\end{array}$ & $\begin{array}{c}\text { Customized to lower the cost of production and improve the efficiency of the work. } \\
\text { With two separate compartments }\left(-5^{\circ} \mathrm{C} \text { and }-5^{\circ} \mathrm{C}\right) \text { having } 9 \text { tonnes storage capacity, ideal for highly } \\
\text { perishable and perishable produce. }\end{array}$ \\
\hline
\end{tabular}

and amygdalin (exclusively for bitter apricot kernel) were studied by authenticated external analytical laboratory (Anacon Laboratory, Nagpur). Box 1 provides a brief description of minor phytochemical parameters conducted internally.

Technology upgradation in the processing unit: For providing improved livelihood opportunity and uplifting the technical skills of women's cooperative members and stakeholders, several updated machinery essential for the production unit were added to the processing unit. Table 3 lists some of the machines installed.

Semi-processing and storage: The primary objective of semi-processing is the preservation of perishable produce in a stable form that can be stored for longer periods. Different methodologies were adapted for semi-processing of selected wild berries, fruits and nuts in a wellequipped Cooperative Centre (HARC Alaknanda Cooperative) in Kaleshwar, Chamoli. Regular trainings were initiated from the beginning of the project involving active participation of women's cooperative members and farmers (Box 2).

\section{Basic techniques followed for preservation}

Blanching: This is a technique in which the fruit or vegetable is briefly immersed in steam or boiling water (40 sec to $1 \mathrm{~min}$ ), usually followed by shocking which is rapidly cooling the food in an ice-bath or with cold air. After shock treatment, the fruit is dipped for $1 \mathrm{~h}$ in $2000 \mathrm{ppm}$ of potassium meta-bisulphite (KMS) $(2 \mathrm{~g} / 1$ of water) solution for colour retention.

Osmotic dehydration: This is the removal of water by immersing food in a solution of salt or sugar of high osmotic pressure. Water is transferred from the food to the solution by virtue of the difference in osmotic pressure. In case of apricot, plum, amla and wild pear (mehal), osmotic infusion is also used as a pre-treatment step prior to processing operations such as convectional drying or freezing, thereby reducing the overall energy requirements in the dehydration process.

Pasteurization: This was done by heating sea-buckthorn juice to a high temperature, viz. $72^{\circ} \mathrm{C}\left(162^{\circ} \mathrm{F}\right)$, and holding for $15 \mathrm{sec}$ (flash method). The process destroys pathogenic microorganisms in certain foods and beverages.

Dehydration: This is a form of drying by artificially produced heat under carefully controlled conditions of temperature, humidity and air flow. It is done using mechanical cabinet dehydrator.

\section{Standardization of recipes for high-value product development}

Standardization of recipes was accomplished after numerous research trials by considering their nutrients in 


\section{Box 2. Brief on processing methodology of different wild produces}

(1) Wild nuts: After the sorting, nuts were decorticated using the decorticator, separated using $15 \%$ brine solution (salt solution), dried through a dehydrator to remove free water to a level where microbial spoilage is reduced for attaining stable shelf-life and finally stored after vacuum packaging in cold storage $\left(5^{\circ} \mathrm{C}\right)$. This method was followed in case of wild walnut, sweet and bitter apricot kernel.

(2) Wild fruits: After sorting and grading, the fruits were washed in the ultrasonic fruit and vegetable washing machine. On the basis of grading, the specific fruits were processed and stored in cold storage. The process mentioned below was followed for wild plum, apricot, peach and pear.

\begin{tabular}{|c|c|c|}
\hline Grading & Processing & Storage \\
\hline Grade A - good quality & $\begin{array}{l}\text { Blanching for } 40 \text { sec } \\
\text { Osmotic dehydration of whole fruit }\end{array}$ & Cold storage $\left(5^{\circ} \mathrm{C}\right)$ \\
\hline Grade B - average quality & $\begin{array}{l}\text { Pulping through pulper or by heating till it is } \\
\text { converted into a soft, shapeless mass }\end{array}$ & $\begin{array}{l}\text { Cold storage in food- } \\
\text { grade drum (SVC) } \\
\left(5^{\circ} \mathrm{C}\right)\end{array}$ \\
\hline Grade C - poor quality & Discarded & - \\
\hline
\end{tabular}

(3) Wild berries: After sorting and grading, the berries were washed using ultrasonic fruit and vegetable washing machine and depending upon the type they were processed and stored in the cold storage $\left(-5^{\circ} \mathrm{C}\right)$.

\section{Processing methodology for wild berries}

\begin{tabular}{|l|l|l|}
\hline Wild berries & \multicolumn{1}{|c|}{ Type } & \multicolumn{1}{c|}{ Process } \\
\hline Sea-buckthorn & Highly perishable & $\begin{array}{l}\text { Direct juice extraction by squeezing method } \\
\text { Pasteurization/addition of preservative (sodium benzoate) } \\
\text { Storage in food grade drums }\left(-5^{\circ} \mathrm{C}\right)\end{array}$ \\
\hline Kafal & Perishable & $\begin{array}{l}\text { Pulp extraction through pulper and addition of preservative (sodium } \\
\text { benzoate) } \\
\text { Storage in food-grade drums }\left(-5^{\circ} \mathrm{C}\right)\end{array}$ \\
\hline
\end{tabular}

Table 4. Household details of 36 selected villages of the targeted area in Chamoli and Rudraprayag districts, Uttarakhand, India

\begin{tabular}{|c|c|c|c|c|c|c|}
\hline Blocks $\longrightarrow$ & Joshimath & Karanprayag & Ghat block & Ukhimath & Pokhri & \multirow{12}{*}{ Total number of $\mathrm{HH}$} \\
\hline \multicolumn{6}{|l|}{ Villages $\downarrow$} & \\
\hline 1 & Jumma & Niwari & Bijar & Chaumasi & Girsa & \\
\hline 2 & Tamak & Khet & Saitoli & Jaal Malla & Sem & \\
\hline 3 & Pangrasu/Fagti & Umrakot-Baidanu & Seti & Chilon & Jilasu & \\
\hline 4 & Suraithota/Tolma & Silangi & Fali & Khunno & & \\
\hline 5 & Saldhar & Sainj & Ustoli & Kotma & & \\
\hline 6 & Dhak & Sunali & Banjbagarh & Bedula & & \\
\hline 7 & Bada Gaon & Kot Kandara & Lankhi Ghingran & Jaggi Bagwan & & \\
\hline 8 & Sunil Gaon & & Kandai Lodla & Byonkhi & & \\
\hline 9 & Parsari & & Pagna & & & \\
\hline $\begin{array}{c}\text { No. of } \\
\text { households }\end{array}$ & 1092 & 480 & 1458 & 967 & 100 & \\
\hline
\end{tabular}

Information generated through scope study conducted in the project area (2016-2017).

order to enhance the nutritional components of these high-value products. Nineteen high-value products were designed after repetitive research and product trials for finalization of quality value-added products, least affecting the nutritional contents. Among them, nine highvalue products were adapted by the HARC Women's Cooperative and incorporated into their business plan. Sensory evaluation was done by following 9-point hedonic scale rating test. Quality packaging material of food- grade quality was customized, and labels were designed with the help of external linkage containing standardized and relevant information.

\section{Results and discussion}

On the basis of nine baseline surveys conducted in the project duration (2016-17), 36 villages were finalized for project intervention (4097 households) (Table 4). 
Table 5. Estimated nutritional content of finalized high-value products

\begin{tabular}{|c|c|c|c|c|c|c|c|c|}
\hline \multirow[b]{2}{*}{$\begin{array}{l}\text { Finalized high-value } \\
\text { products }\end{array}$} & \multicolumn{8}{|c|}{ Nutritional value } \\
\hline & $\begin{array}{l}\text { Sugar } \\
(\mathrm{g} / 100 \mathrm{~g})\end{array}$ & $\begin{array}{c}\text { Energy } \\
\text { value } \\
(\mathrm{kcal} / 100 \mathrm{~g})\end{array}$ & $\begin{array}{l}\text { Carbohydrate } \\
(\mathrm{g} / 100 \mathrm{~g})\end{array}$ & $\begin{array}{l}\text { Total fat } \\
(\mathrm{g} / 100 \mathrm{~g})\end{array}$ & $\begin{array}{l}\text { Protein } \\
(\mathrm{g} / 100 \mathrm{~g})\end{array}$ & $\begin{array}{l}\text { Vitamins } \\
(\mu \mathrm{g} / 100 \mathrm{~g})\end{array}$ & $\begin{array}{l}\text { Minerals } \\
(\mathrm{mg} / 100 \mathrm{~g})\end{array}$ & $\begin{array}{l}\text { Shelf-life } \\
\text { (months) }\end{array}$ \\
\hline Apricot chutney & 55 & 214.34 & 50.97 & 0.14 & 2.3 & $1180(\mathrm{E})$ & - & 6 \\
\hline Sea-buckthorn nectar & & 95.32 & 23.62 & 0.08 & 0.03 & $235.6(\mathrm{C})$ & $850(\mathrm{Na})$ & 6 \\
\hline Amla madhu prash & 14.52 & 348.26 & 75.88 & 1.58 & 7.63 & $28150(\mathrm{~A})$ & $90(\mathrm{Na})$ & 12 \\
\hline Walnut salsa & 3.49 & 286.97 & 63.66 & 3.33 & 0.59 & $1060 \mathrm{IU}(\mathrm{E})$ & $640(\mathrm{Na})$ & 6 \\
\hline Kaphal nectar & 2.31 & 104.63 & 25.88 & 0.03 & 0.21 & $190(\mathrm{C})$ & $75.78(\mathrm{Ca})$ & 6 \\
\hline Sea-buckthorn concentrate & - & 45.21 & 10.45 & 0.09 & 0.65 & $156.7(\mathrm{C})$ & $350(\mathrm{~K})$ & 12 \\
\hline Plum chutney & 58 & 267.75 & 65.83 & 0.15 & 0.77 & $215 \mathrm{IU}(\mathrm{E})$ & $1860(\mathrm{Na})$ & 6 \\
\hline Peach chutney & 55 & 256.06 & 62.88 & 0.14 & 0.82 & $198 \mathrm{IU}(\mathrm{E})$ & $1430(\mathrm{Na})$ & 6 \\
\hline Roasted nuts & 1.77 & 638.95 & 16.9 & 52.75 & 24.15 & $8700(\mathrm{E})$ & $590.8(\mathrm{~K})$ & 6 \\
\hline Walnut honey dip & 6.13 & 305.2 & 66.69 & 12.58 & 9.61 & 516 IU(A) & $290(\mathrm{~K})$ & 6 \\
\hline Apricot bar & 22.66 & 355.21 & 80.66 & 2.73 & 2 & $118500(\mathrm{C})$ & $1024.06(\mathrm{Na})$ & 6 \\
\hline Granola bar & 18.61 & 420.85 & 78.91 & 9.41 & 5.13 & $20 \mathrm{IU}(\mathrm{E})$ & $2185.85(\mathrm{Na})$ & 6 \\
\hline Walnut honey bar & 5.87 & 371.65 & 79.49 & 3.69 & 5.12 & $3100(\mathrm{C})$ & $1815.67(\mathrm{Na})$ & 6 \\
\hline Apricot oil & \multicolumn{5}{|c|}{ Oleic acid: $73.5 \mathrm{~g} / 100 \mathrm{~g}$ and linoleic acid: $26.28 \mathrm{~g} / 100 \mathrm{~g}$} & $6580(\mathrm{E})$ & & 24 \\
\hline
\end{tabular}

*Source: External laboratory (Anacon Laboratory, Nagpur). IU, International Unit.

After conducting this survey, it was found that these wild crops are abundant in the forest area, even after being consumed by wild and domestic animals. Residing farmers harvest a small amount of these crops according to their needs. No management as well as storage practices have been adopted by the villagers for these crops.

Broadly, through phytochemical analysis, major chemical properties of selected wild produces were determined (Table 4). Sea buckthorn was estimated to have the highest ascorbic acid (600 mg/100 g; vitamin C). Highest antioxidant activity was shown in sweet apricot kernel $(58.82 \%)$, making it beneficial for humans, whereas, wild plum showed maximum amount of carotene $(2835 \mu \mathrm{g} /$ $100 \mathrm{~g})$. For phenolic content, kaphal was detected to show the highest value $(1.37 \mathrm{mg} / 100 \mathrm{ml})$. The oleic acid content in bitter apricot kernel was $35.78 \%$, signifying large amounts of omega-3 fatty acid. Amygdalin in bitter apricot kernel was also estimated to analyse its toxicity, which was about $0.89 \%$, indicating its anti-cancerous properties.

Apricot oil contained $73.5 \mathrm{~g} / 100 \mathrm{~g}$ of oleic acid, acting as a moisturizing agent and a rich source of vitamin $\mathrm{E}$ $(6580 \mu \mathrm{g} / 100 \mathrm{~g})$. Roasted nuts are considered to be the richest source of energy $(638.95 \mathrm{kcal} / 100 \mathrm{~g})$ and proteins $(24.15 \mathrm{~g} / 100 \mathrm{~g})$, among other designed products. With regard to nutritional content, apricot bar had the richest source of carbohydrates $(80.66 \mathrm{~g} / 100 \mathrm{~g})$.

\section{Conclusion and recommendation}

Through this intervention, 14 high-value products were successfully developed and launched by the HARC Alaknanda Women's Cooperative (Table 5). Standardized process related to harvesting, collection, transportation, semi-processing and value addition was accomplished with the complete involvement of stakeholders in the form of SOPs, while conducting this action research. The local relationship and linkage among the stakeholders were developed and strengthened for sustainable development and intervention in the Himalayan region of Uttarakhand. Trainings on pre- and post-harvest technologies, machine-handling, package of practices, etc. were simultaneously provided to cooperative women and about 114 women were trained in collection, semi-processing, product development and machinery handling. Nine highvalue products were incorporated into their business plan and about income of Rs 1 crore was generated by the Cooperative in last year of the project (2019). Through this intervention, farmer income of about Rs 25 lakhs was generated through collection, transportation and semiprocessing of raw materials and it took two years for technology transfer and knowledge-building among farmers and cooperative members. Thus we can conclude that value addition of wild produce is one of the best ways to restore biodiversity and generating better livelihood options leading to food and economic security of the Himalayan communities. This study has set up a replicable model for sustainable income-generation and individual entrepreneurs in the Himalayan region.

1. Tiwari, J. K., Ballabha, R. and Tiwar, P., Some promising wild edible plants of Srinagar and its adjacent area in Alaknanda Valley of Garhwal Himalaya, India. J. Am. Sci., 2010, 6(4), 167-174.

2. Meyers, K. J., Watkins, C. B., Pritts, M. P. and Liu, R. H., Antioxidant and anti proliferative activities of strawberries. J. Agric. Food Chem., 2003, 51(23), 6887-6892.

3. Saklani, S., Chandra, S. and Mishra, A. P., Evaluation of nutritional profile, medicinal value and quantitative estimation in different parts of Pyrus pashia, Ficus palmate and Pyracantha crenulata. J. Global Trends Pharm. Sci., 2011, 2(3), 350-354.

4. Uniyal, B. and Shiva, V., Traditional knowledge on medicinal plants among rural women of Garhwal Himalaya, Uttaranchal. Indian J. Trad. Knowl., 2005, 4(3), 259-266. 
5. World Bank, Expanding women's access to financial services, 2014; http://www.worldbank.org/en/results/2013/04/01/banking-onwomen-extending-womens-access-to-financial-services (accessed on 12 December 2017).

6. Samant, S. S., Dhar, U. and Palni, L. M. S., Medicinal Plants of Indian Himalaya: Diversity Distribution and Potential Values, Gyanodaya Prakashan, Nanital, 1998.

7. Sharma, R., Diversity, endemism and economic potential of wild edible plants in Chopta-Mandal forest and vicinity of Garhwal Himalayas in Uttarakhand, 2014; http://ndl.handle.net/10603/ 43686.

8. Sharma, R., Gupta, A., Abrol, G. S. and Joshi, V. K., Value addition of wild apricot fruits grown in North-West Himalayan regions - a review. J. Food Sci. Technol., 2014, 51(11), 2917-2924.

9. FAO, The state of food and agriculture 1995. Food and Agriculture Organization of the United Nations, Rome, Italy, 1995.

10. Rongsen, L., Sea buckthorn: a multipurpose plant species for fragile mountains. Occasional Paper No. 20, International Centre for Integrated Mountain Development, Kathmandu, Nepal, 1992, p. 63.

11. Li, T. S. C., Product development of sea buckthorn. In Trends in New Crops and Issues (eds Janick, J. and Whipkey, A.), ASHS Press, Alexandria, USA, 2002, pp. 393-398.

12. Stobdan, T., Angchuk, D. and Singh, S. B., Sea-buckthorn: an emerging storehouse for researchers in India. Curr. Sci., 2008, 94, 1236-1237.
13. Banerji, G. and Fareedi, M., Sustainable livelihoods for high altitude mountain communities, Case Studies from the Himalayas, Pragya, www.pragya.org.

14. AOAC, Official Methods of Analysis, Association of Official Analytical Chemists, Arlington, VA, USA, 1984, 14th edn.

15. AOAC, Official Methods of Analysis of the AOAC, Association of Official Analytical Chemists. Arlington, VA, USA, 1990, 15th edn.

16. Rangana, S., Handbook of Analysis and Quality Control for Fruits and Vegetable Products, CSIR-Central Food Technological Research Institute, Mysuru, 1997, 2nd edn.

ACKNOWLEDGEMENTS. We thank the National Mission on Himalayan Studies for funds, our technical partner Uttarakhand State Council for Science and Technology and our implementing partner HARC Alaknanda Women's Cooperative which helped conduct all action research under this project. Funding source: National Mission on Himalayan Studies, Ministry of Environment, Forest \& Climate Change, Government of India, Nodal and Serving Hub-G.B Pant National Institute of Himalayan Environment and Sustainable Development, Uttarakhand State Council for Science and Technology, Department of Science \& Technology (Government of Uttarakhand).

doi: $10.18520 / \mathrm{cs} / \mathrm{v} 120 / \mathrm{i} 5 / 818-824$ 